\title{
Effect of Firm Characteristics on the Financial Performance of Commercial Banks in Kenya
}

\author{
Joan Jebet ${ }^{*} \quad$ Joshua Matanda Wepukhulu \\ School of Business, Jomo Kenyatta University of Agriculture and Technology P.O. Box $62000-00200$ Nairobi, \\ Kenya
}

\begin{abstract}
The study aimed to examine the effect of firm characteristics on the financial performance of commercial banks in Kenya by examining the effect of capital adequacy liquidity, credit risk and bank size on the financial performance. A descriptive research design was used in the study. The study focused on the 36 commercial banks which had complete dataset for the period 2013 - 2018. The study used secondary data acquired from the published yearly financial documents gathered from the Central Bank of Kenya. Analysis of the data was carried out using the STATA software. The relationship between independent and dependent variables was analyzed using descriptive statistics and panel data regression analysis while the strength between the variables was determined using correlation. The financial performance was measured using Return on Equity. Results on the regression models indicated that capital adequacy and bank size had a positive effect on the return on equity of the commercial banks in Kenya. Liquidity and credit risk were found to have a negative effect on the return on equity of the commercial banks in Kenya.
\end{abstract}

Keywords: Capital Adequacy, Credit risk, Liquidity, Bank Size, Return on Equity

DOI: $10.7176 /$ RJFA/11-22-06

Publication date: November $30^{\text {th }} 2020$

\section{Introduction}

\subsection{Background of the Study}

Globally, banking watchdogs have concentrated on invigorating the benefit of capital and liquidity standards of the banking institutions for the past decade. Those endeavors have prompted a similarly robust obligation addressing the disproportion and intricacy of the worldwide capital system for universally dynamic banking institutions, with administrative union activities, for example, Basel III focuses on resolution administrations formulating the tone for a progressively unswerving banking rulebook from a substantial number of jurisdictions.

According to a 2014 KPMG report, banking establishments found it tough to act by the new guidelines after the 2008 financial crisis. The regulations brought about increased rates of profitability reduction. A similar report on banking institutions in Europe found out that there were sizeable profits and credit costs diminution after the enactment of new guidelines as compared to the 2007 peaks (Chiarella, 2011).

Regionally, a higher rate of failure had marred several African economies. The Nigerian banking sector is a key example as it operated in an unregulated and free setup. At the time, most of the banking institutions could not get up from any economic shocks as they had very little capital. The catastrophe facing banking establishments was unrelenting despite enacting the first banking law. However, the CBN became the overall regulatory body of the banking sector in 1959 , and it is when the sector began to change for the better.

The Nigerian economy was vastly affected by the 2008 global financial crisis. This saw the financial sector suffering the most as it could not withstand the substantial economic shocks. According to Chowdhury (2018), the 2007 global financial crisis was a result of regulatory failure. Chowdhury (2018) categorized the regulatory failure in two, economic regulation and prudential regulation. The maintenance of interest rates and credit allocation was supported by economic regulation while the prudential regulation safeguarded the depositors and financial systems stability.

In the Kenyan context, On 31 December 2016, about twelve banking institutions violated CBK's banking Act and Prudential rules as compared to 4 banks on 31 December 2015 (CBK, 2017). Chase bank was put on receivership after it encroached on the liquidity portion set for banking institutions by the CBK. Seven banks out of the 12 had violated the Prudential Rules and Banking Act's liquidity administration regulations that require the banking institutions to have a 20\% or higher liquidity proportion (CBK, 2017). Further, in April 2016, Chase bank was put on receivership leading to a diminishing of the certainty levels, and this led to an activation of the freeze withdrawal of little and medium-sized banks stores. As of December 2016, the year-on-year client stores grew by 5.3\% to KSH 2.62 trillion (CBK, 2017). However, a large portion was taken up by expansive banking institutions following the banking crisis. In addition, Family Bank of Kenya was linked to an NYS scandal on November 2016, and this saw it misplacing deposits worth KSH 21.3 billion leaving it with a $14.4 \%$ liquidity proportion that is $5.6 \%$ points below the CBK has set the threshold as the year ended (Otiato, 2017; Family Bank, 2017). However, the bank could regain back its steps despite the setbacks. 


\subsection{Statement of the problem}

The role of the financial institutions cannot be over-emphasized given their critical role in financial intermediation. Given their critical role a stable finacial system is highly desirable. This implies that they must be regulated, controlled, and administered to ensure that they have a solid and secure financial base. However, one evident fact is that any form of directive imposed against the banking institutions is bound to have an impact on operational proficiency and leads. Currently the money related markets are heavily regulated then before. This oversight has brought about improved trust within the sector. However, it is at times hard for one to point-out any identifiable variations between chocking out the opportunities and re-establishing trust.

The effect of firm characteristics on the financial performance of financial institutions has been studies by various scholars both locally and internationally. The different studies have come up with similar and different results. However, the findings of the different studies have been largely inconclusive. Kenyan banking industry like any other banking industry world - wide is highly regulated. This is because banking industry accounts for the largest share of the total financial sector's assets thus making the sector bank - led financial sector. This demonstrates the crucial importance of the banking industry in so far as the financial sector is concerned. However, despite this high level of regulation the recent past years have seen three banks put into receivership in a span of two years. Some banks also have recorded below required thresholds on some key performance indicators such as the 20 percent liquidity level requirement.

In 2013 following the amendment of Banking Act, new CBK prudential guidelines were formulated. Two years after the new Act saw three commercial banks were placed under liquidation (Chase Bank, Dubai bank and Imperial bank) between 2015 and 2016. The banks engaged in fraudulent financial activities and had huge capital deficiencies. Other banks suffered huge losses such as National Bank of Kenya that had a KSH 1.2 billion loss in 2015, and CFC had a KSH 1 billion loss in 2015 (National Bank, 2016; CFC Annual Report, 2015). This is an indication that despite the introduction of the 2013 CBK prudential guidelines, some commercial banks still faced difficulties. However, other banks such as Equity bank, Kenya Commercial bank and Co-op bank had increased revenues within the same period (Central Bank of Kenya Annual Report, 2015).This is an indication that there is a mixed outcome with regards to the implementation of the regulation and the financial performance of the commercial banks. The outcomes of increased regulation have seen the launching of debate on bank consolidation that is still ongoing. The aim of this research is thus to thoroughly scrutinize the effect of firm characteristics on the financial performance of the commercial banks in Kenya and resolve the conflict from previous findings hence addressing the research gap.

\subsection{Objectives of the Study}

\subsubsection{General Objective of the Study}

The study's core objective was to determine the effect of firm characteristics on financial performance of commercial banks in Kenya.

\subsubsection{Study Specific Objectives}

The following objectives guided the study;

i. To determine the effect of capital adequacy on the financial performance of commercial banks in Kenya

ii. To determine the effect of credit risk on the financial performance of commercial banks in Kenya

iii. To determine the effect of liquidity on the financial performance of commercial banks in Kenya

iv. To determine the effect of bank size on the financial performance of commercial banks in Kenya

\subsection{Literature Review}

\subsection{Theoretical Framework}

The Agency theory is based on the idea that a relationship arises when one or more parties contract another to perform on their behalf a task and delegates the pronouncement creation power to the hired party (Jensen \& Meekling, 1976). Agency theory is relevant to the capital adequacy requirements of commercial banks. Asymmetric information and underpriced debts have been said to play a vital role as to why bank capital requirements are vital. Data asymmetry problems are grander than in different decisions in the general financial framework and bank regulations. According to Howells and Bain (2004), they indicate that the availability of asymmetric information can be used in explaining bank controls. This arises from the fact that the banks have a much higher literacy level concerning their operations as compared to their customers. The bank's clients would want higher levels of security before dealing with the institutions because of the insufficiency or non-existence market rivalry.

In addition, Stakeholder theory was propounded by Freeman (1984), and Friedman \& Miles (2002). The theory advocated for the importance of the firm to represent the needs of all stakeholders to achieve corporate goals. It states that one way of generating sustainable profits for the firm is meeting the needs of the stakeholders. These stakeholders include customers, the community, the employees, and the organization. Duckworth \& Moore (2010) states that for a firm to achieve sustainable profit, the firm should accommodate the various needs of the 
stakeholders. The importance of this theory is that the stakeholders are key players of the bank and the satisfaction of their needs is vital in the realization of corporate goals. Bank profitability has been linked with meeting the needs of the stakeholders. Friedman and Miles (2002) argue that firms that exhibit high profitability meet the needs of all their stakeholders. This means that banks need to establish a good relationship with its stakeholders to attain sustainable profitability.

\subsection{Conceptual framework}

The conceptual framework outlines the relationship between the dependent and independent variables. In this research, the liquidity, credit risk, capital adequacy and bank size will represent the independent variables while the commercial bank's financial performance will represent the dependent variable. The figure below outlines the study's dependent and independent variables relationships;

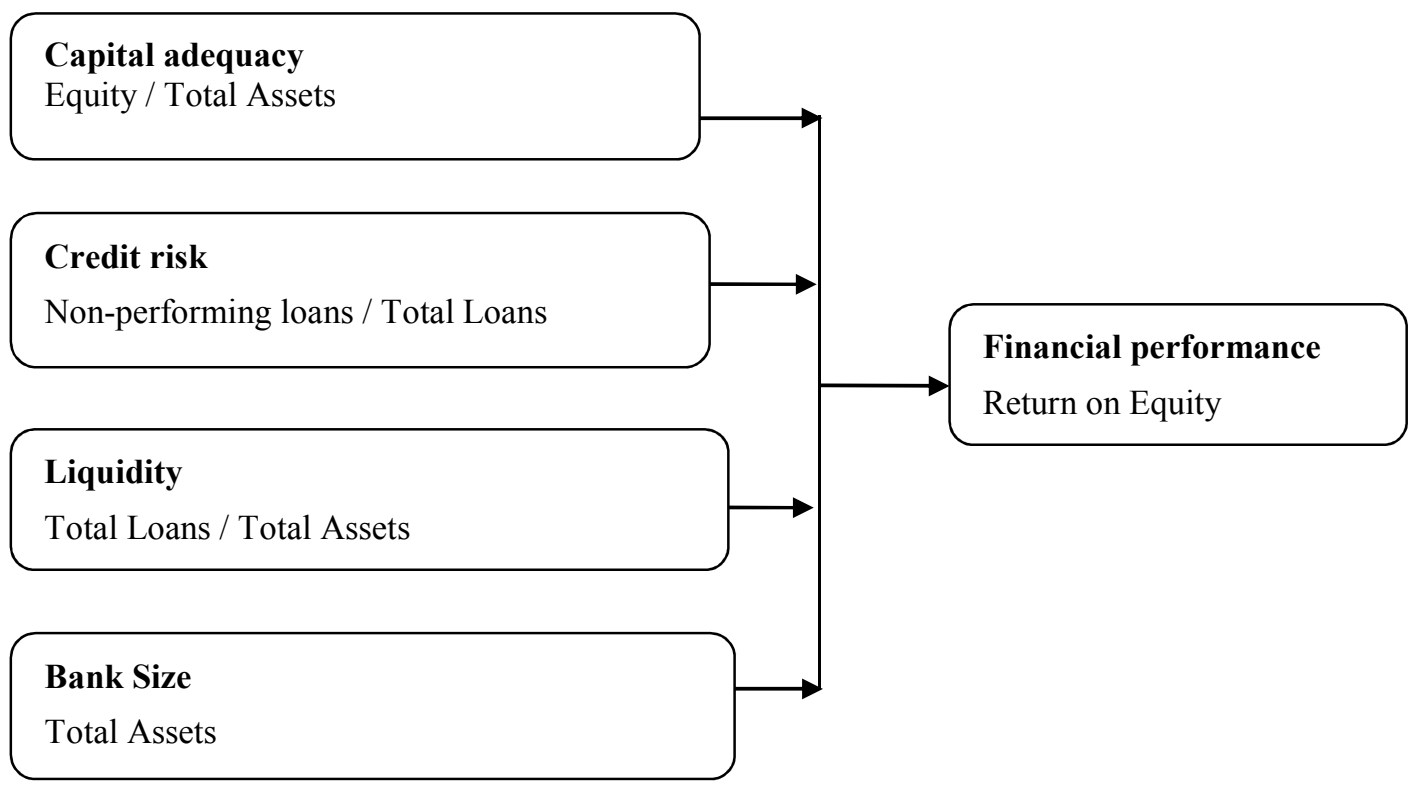

Figure 1.1: Conceptual Framework

\subsection{Empirical Review}

\subsubsection{Capital adequacy and financial performance}

From the empirical reviews of capital adequacy - financial performance nexus, Berger and Bouwman (2013) state that there are a relationship and significant impact on capital ampleness on global bank gainfulness basing on a study conducted from various banking institutions in the USA. Ogboi and Unuafe (2013) used a sample of 6 Nigerian based commercial banks aimed at determining the impact of capital adequacy on their financial performance for $2004-2009$. The study found that the banks' money related execution was emphatically affected by the capital adequacy. However, during the period of study, the loans and advances affected the banks' benefit negatively.

Chinada (2015) examined the effect of least capital prerequisites on Zimbabwean banks performance and to break down the connection concerning the banking institutions least capital necessities and the performance. The investigation discovered that Minimum capital prerequisite enables banking institutions to redeem benefits as meeting the base capital diminishes the probabilities of bank misfortunes, as short-term borrowing will not compel the institutions, which is commonly at an astonishing cost. A bank with sufficient capital was found to have a competitive advantage in its operational market as it can offer more items and this makes it more focused on its operations; hence, it can capture a bigger market share.

Naceur (2009) found out that the capital sufficiency proportion disguises the hazard for investors; banks increased the expense of intermediation, which underpins more returns on equity and assets basing on an Egyptian based study on the effects of capital requirements on the performance cost and intermediation of banking institutions. The impacts seem to dynamically increase in the end, beginning from when capital guidelines are presented and proceeding with two years after the usage. Regardless, the proof does not bolster the speculation of a supported impact of capital directions after a period or difference related to the impacts with the capital measure being crosswise over banks.

Murkomen (2013) found out that the core capital to total risk-weighted assets ratio has a strong and positive connection with the operating efficiency in a study carried out on Kenyan commercial banks to determine the 
impacts of capital requirement on operating efficiency. Nekesa (2017) found out that capital sufficiency contributes decidedly to an organization's financial performance basing on a study carried out on firms listed on the Kenyan Nairobi Securities Exchange.

\subsubsection{Credit risk and financial performance}

On credit risk - financial performance nexus, Poudel (2012) analysed 31 Nepalese commercial banks for 2000 2011 period. The study found that credit risk had an inverse relationship with the banking institutions financial performance. Kargi (2011) carried out a study on Nigerian based banking institutions between 2004 and 2008 to determine whether profitability is affected by credit risks. The study findings were that the levels of advances, loans, deposits, and non-performing loans were also found to have an inverse effect on banks' profitability. In the Kenyan, context, Mureithi (2012) carried out a study on Kenyan commercial banks to determine the impact of credit risk on their financial performance between 2005 and 2014. The study found a negative relationship between banks profitability and credit risk.

\subsubsection{Liquidity and financial performance}

Review of the relationship of bank liquidity and financial performance of bank also reveal inconclusive findings in the study findings. A Pakistan based study on Habib bank limited was conducted for the period 2008-2014 by Rizwan \& Mutahhar (2006) found out that there is a significant positive relationship between the banks' liquidity and profitability. Oblior (2013) studied 3 Nigerian banks to examine the impacts of liquidity management on their profitability. The study used proxies representing profitability (profit after tax) and liquidity management (bills and certificates, bank balances and treasury and cash and short-term funds). The study concluded a positive effect of bank liquidity on financial performance.

Muriithi (2017) examined the impacts of financial performance and liquidity risk on their operations. The study results were that short -term profitability of the banks had a negative relationship with liquidity risk. However, the study found no significant relationship between long - term financial profitability and bank liquidity levels. Nonetheless, the study's general finding was that liquidity risk hurts commercial banks financial performance.

\subsubsection{Bank size and financial performance}

About effect of bank size on financial performance of commercial banks, Dogan, (2013), carried out a study to determine whether firm size affects the firm profitability for 200 companies listed in Istanbul Stock Exchange $2008-2011$ period. The result of analysis indicated a positive relation between bank size and profitability of firms. Mbekomize and Mapharing (2017) analysed the determinants of profitability of commercial banks in Botswana. The research findings established that a statistically insignificant relationship existed between bank size and all the measures of bank profitability. A positive relationship existed between bank size and profitability as measured ROA whereas a negative relationship existed between bank size and ROE. Gatete (2015) carried out a study on the effect of bank size on the profitability of commercial banks in Kenya for $2010-2015$ for 43 commercial banks. The research findings established that firm size is statistically significant and moderately positively correlated to profitability of commercial banks in Kenya. Liquidity, operating efficiency, and capital adequacy were found to be statistically insignificant.

\subsection{Methodology \\ 3.1 Research Design}

The study adopted a quantitative research design. This is because the study relied on the secondary data for empirical analysis. More specifically, the study adopted a descriptive research design. A descriptive research design was used in the study as it allowed the researcher to pinpoint any form of relationship between the study variables (Sekaran, 2011). The adoption of the descriptive research design is informed by its ability to explore and in-depth description on how firm characteristics regarding liquidity, capital adequacy, bank size and credit risk affect the return on equity of the commercial banks.

\subsection{Target Population}

The target population of the study was 43 commercial banks in Kenya under the regulation of the Central Bank of Kenya as at the year 2018. The study focused on the 36 commercial banks which had complete dataset for the period $2013-2018$. The banks eliminated from the analysis were the recently acquired banks whose data for 2018 was unavailable. These were Fidelity banks, Habib Bank and Giro Bank. Further were the banks that recently entered the market: - SBM bank, Mayfair bank and Dubai Islamic Bank whose data for 2013 - 2017 was unavailable. In addition, was the elimination of the collapsed banks which are under liquidation and statutory management: - Dubai bank, Imperial bank, Chase Bank and Charter House bank. The elimination of these banks was to ensure that the panel data was a balanced panel thus avoiding problems of estimation arising from using unbalanced panel data.

\subsection{Data Analysis}

The study relied on panel data. According to Baltagi (2005), panel data eliminates the presence of parameter 
estimator biases by allowing the researcher to have access to cross-sectional dimensions and time series. The data was gathered for a period of 6 years (2013-2018) from 43 Kenyan based commercial banks. Panel data analysis will involve the use of random effects model. In addition to the estimation of the regression model, the analyses will undertake Pearson correlational test among the variables to establish the relationships among the variables. Further, is the descriptive statistics to explain the general distribution and characteristics of the variables. The analysis will also entail the hypotheses testing based on the estimated model coefficients. The regression model for the study is presented in equation 3.1 as follows:

$Y_{i t}=\alpha_{0}+\beta_{1} X 1_{i t}+\beta_{2} X 2_{i t}+\beta_{3} X 3_{i t}+\beta_{4} X 4_{i t}+\varepsilon_{t} \ldots \ldots$ (3.1)

Where: $Y$ is the dependent variable of the model, $X(s)$ are the independent variables of the model, $\beta(s)$ are the coefficients of the independent variables to be estimated and $\varepsilon$ is the error term for the model. The specific empirical model for the study was defined as follows in model 3.2:

$R O E_{i t}=\alpha_{0}+\beta_{1}$ Capital adequac $_{i t}+\beta_{2}$ Liquidity $_{i t}+\beta_{3}$ Credit Risk $_{\text {it }}+\beta_{4}$ Banksize $_{i t}+\varepsilon_{t}$

Where: Capital Adequacy is the capital adequacy of bank $i$ in period $t$; Liquidity is the liquidity levels of bank $i$ in period $t$; Credit risk is the credit risk exposure of bank $i$ in period $t$ and Bank size is the size of bank $i$ in period t.

\subsection{Research findings and Discussion}

\subsection{Descriptive statistics}

The descriptive statistics reported in table 1.1 indicate that in total there were 216 observations. The results show that the mean of Return on equity was 12.83 percent for period under analysis with the minimum value of -41.0 percent and maximum of 49.40 percent. On the distribution, return on equity has a negative skewness of -0.9127 and non - normally distributed as evidenced by kurtosis value of 3.7327 , which is greater than 3 for a normally distributed variable. The mean for capital adequacy was 0.1745 percent with a minimum value of -11.17 percent and maximum of 159.38 percent. On the distribution, the capital adequacy had a positive skewness of 8.2411 but was non - normally distributed as evidenced by kurtosis value of 9.1074 which is greater than 3 implying that it was fat - tailed.

The mean of credit risk was 0.1123 percent with minimum of 0.0056 and maximum level of 0.6962 . The distribution of credit risk portrayed a positive skewness of 1.9733 but was fat - tailed with a kurtosis value of 7.5651 which is greater than 3.0 kurtosis value of a normally distributed variable. The mean of liquidity risk was 0.6067 with minimum of 0.0424 and maximum level of 5.5147. The skewness was positive skewness of 11.4337 with a non - normal distribution of 15.5855 kurtosis value implying fat tails in its distribution. The mean bank size was 17.5465 with minimum of 14.8884 and maximum level of 20.248 . The skewness was positive skewness of 0.2218 with a non - normal distribution of 1.8162 kurtosis value implying fat tails in its distribution.

In overall, on the distribution of the variables, results indicate that all variables have positive skew to their mean values except for the return on equity. Further, on the distribution still, all variables are non - normally distributed as evidenced by their respective kurtosis. However, it is notable that statistically, financial data is deemed to be leptokurtic thus negating the assumption of normal distribution.

Table 1.1: Descriptive Statistics

\begin{tabular}{|c|c|c|c|c|c|c|c|c|c|}
\hline \multicolumn{2}{|l|}{ Variables } & \multirow{2}{*}{$\begin{array}{c}\text { Mean } \\
12.8287\end{array}$} & \multirow{2}{*}{$\frac{\text { Std. Dev. }}{17.4518}$} & \multirow{2}{*}{$\begin{array}{c}\text { Min } \\
-41\end{array}$} & \multirow{2}{*}{$\begin{array}{c}\text { Max } \\
49.4\end{array}$} & \multirow{2}{*}{$\begin{array}{c}\text { Skewness } \\
-0.9127\end{array}$} & \multirow{2}{*}{$\begin{array}{c}\text { Kurtosis } \\
3.7327\end{array}$} & \multicolumn{2}{|c|}{ Obs } \\
\hline & Overall & & & & & & & $\mathrm{N}=$ & 216 \\
\hline KUE & Between & & 15.0503 & -20.7833 & 42.2667 & & & $\mathrm{n}=$ & 36 \\
\hline & Within & & 9.1281 & -21.9546 & 47.7454 & & & $\mathrm{~T}=$ & 6 \\
\hline \multirow{3}{*}{ Capital Adequacy } & Overall & 0.1745 & 0.1221 & -0.1117 & 1.5938 & 8.2411 & 9.1074 & $\mathrm{~N}=$ & 216 \\
\hline & Between & & 0.0593 & 0.0773 & 0.4101 & & & $\mathrm{n}=$ & 36 \\
\hline & Within & & 0.1072 & -0.0941 & 1.3582 & & & $\mathrm{~T}=$ & 6 \\
\hline \multirow{3}{*}{ Credit Risk } & Overall & 0.1123 & 0.1105 & 0.0056 & 0.6962 & 1.9733 & 7.5651 & $\mathrm{~N}=$ & 216 \\
\hline & Between & & 0.0804 & 0.0129 & 0.3111 & & & $\mathrm{n}=$ & 36 \\
\hline & Within & & 0.0767 & -0.1253 & 0.6240 & & & $\mathrm{~T}=$ & 6 \\
\hline \multirow{3}{*}{ Liquidity } & Overall & 0.6067 & 0.3632 & 0.0424 & 5.5147 & 11.4337 & 15.5855 & $\mathrm{~N}=$ & 216 \\
\hline & Between & & 0.1736 & 0.3091 & 1.3598 & & & $\mathrm{n}=$ & 36 \\
\hline & Within & & 0.3202 & -0.3253 & 4.7616 & & & $\mathrm{~T}=$ & 6 \\
\hline \multirow{3}{*}{ Bank size } & Overall & 17.5465 & 1.3102 & 14.8884 & 20.248 & 0.2218 & 1.8162 & $\mathrm{~N}=$ & 216 \\
\hline & Between & & 1.3019 & 15.5445 & 19.9384 & & & $\mathrm{n}=$ & 36 \\
\hline & Within & & 0.2467 & 15.7082 & 18.5352 & & & $\mathrm{~T}=$ & 6 \\
\hline
\end{tabular}

\subsection{Correlation Analysis}

The correlation coefficients results indicate that the bank return on equity is negatively related to liquidity and 
credit risk and positively related to capital adequacy and bank size. However, the Pearson correlation coefficients reveal that the correlations are moderate as they are below the 50 percent. In overall looking at the correlation coefficient among all the model variables, the correlation analysis reveals that there are no two variables that are strongly correlated with each other hence no possibilities of multicollinearity especially when running the pooled OLS model.

Table 1.2: Correlation matrix

\begin{tabular}{|c|c|c|c|c|c|}
\hline Variables & ROE & Capital adequacy & $\begin{array}{l}\text { Credit } \\
\text { Risk }\end{array}$ & Liquidity & Bank size \\
\hline ROE & 1.000 & & & & \\
\hline Capital adequacy & $\begin{array}{c}0.1781 \\
(0.0087)\end{array}$ & 1.000 & & & \\
\hline Credit risk & $\begin{array}{c}-0.4988 \\
(0.0000)\end{array}$ & $\begin{array}{c}-0.0499 \\
(0.4654)\end{array}$ & 1.000 & & \\
\hline Liquidity & $\begin{array}{c}-0.1685 \\
(0.0131)\end{array}$ & $\begin{array}{c}0.3507 \\
(0.0000)\end{array}$ & $\begin{array}{c}0.0696 \\
(0.3085)\end{array}$ & 1.000 & \\
\hline Bank size & $\begin{array}{c}0.6279 \\
(0.0000)\end{array}$ & $\begin{array}{c}-0.1431 \\
(0.0356)\end{array}$ & $\begin{array}{c}-0.2708 \\
(0.0001)\end{array}$ & $\begin{array}{c}-0.0749 \\
(0.2732)\end{array}$ & 1.000 \\
\hline
\end{tabular}

Note: significance levels are in parenthesis

\subsection{Diagnostic Tests}

The following diagnostic tests were carried out to evaluate the suitability of the research model.

\subsubsection{Hausman test}

Hausman test is used to differentiate between fixed effects model and random effects model in panel data. Random effects is preferred under the null hypothesis due to higher efficiency, while under the alternative hypothesis, fixed effects model is at least consistent and thus preferred. The Hausman results indicate a chi2 value of 12.41 with Pvalue of 0.1450 (Prob $>$ chi $2=0.105)$. Since the $\mathrm{p}$ - value of the chi 2 is greater than the 5 percent significance level then random effects model is selected as the most appropriate model.

\subsubsection{Multicollinearity Test}

Multicollinearity is a regression problem that arises from interrelation between the independent variables in a model. To test for multicollinearity, the Variance Inflation Factors (VIF) was applied. The VIF test results indicate that the mean variance inflation factor was equal to 1.13 . Using a rule of thumb of 10 , we conclude that there is no multicollinearity among the variables since the mean VIF for both models are less than 10 .

\subsubsection{Heteroscedasticity Test}

Heteroscedasticity is an econometric problem of not constant but rather keeps on changing. The presence of heteroscedasticity problem implies that the estimated model coefficients are not Best, Linear and Unbiased Estimators (BLUE). This further implies that any hypothesis testing carried out using such coefficients and their respective standard errors would be inconsistent. To test for the heteroscedasticity problem, Breusch-PaganGodfrey test was used. The results show that the Chi2 for the test was 31.60 with the Probability values for the chi square statistics being 0.1629 (Prob $>$ chi2 $=0.1463$ ). The probability of the Breusch-Godfrey LM is greater than 5 percent indicating absence of heteroscedasticity in the model.

\subsubsection{Autocorrelation Test}

Wooldridge test for autocorrelation was used to test for presence of autocorrelation in the pooled data. In testing for the serial correlation within the pooled OLS models, alternative Durbin Watson test was applied. First, the OLS model was estimated and the autocorrelation test carried out. The results of the test are presented in table 1.6. From the results, the Probability value for the $F$ - statistics greater than 5 percent $(p-$ value $>0.4179)$ indicating absence of autocorrelation. The results therefore conclude absence of any serial correlation from the errors.

\subsection{Regression Analysis - Random effects model}

Upon the selection of the random effects model by the Hausman test, the model was used to estimate to the effect of firm characteristics on the financial performance of commercial banks. The firm characteristics included in the empirical model were capital adequacy, liquidity levels, credit risk and bank size. The results for the three models are presented in table 1.3

Results on the regression models indicated that capital adequacy had a positive effect on the return on equity of the commercial banks in Kenya. The effect was found to be significant at 10 percent significance level (P value $=0.071$ ). Empirical models results indicate that a one-unit increase in the capital adequacy levels above the minimum requirement increases the banks return on equity by 11.8177 units holding other factors constant. The capital adequacy ratio, also generally known as capital to risk-weighted assets ratio, measures a bank's financial strength by using its capital and assets. Banks with higher capital adequacy ratio above the minimum requirement by the regulator are perceived to be more stable and efficient. This is because a bank with a high capital adequacy 
ratio is considered safe and likely to meet its financial obligations. This builds confidence of the investors and the customers as well thus having a positive effect on the overall banks' performance. The finding on the effect of capital adequacy requirement is in agreement with the finding by Murkomen (2013) found out that the core capital to total risk-weighted assets ratio has a strong and positive connection with the operating efficiency in a study carried out on Kenyan commercial banks to determine the impacts of capital requirement on operating efficiency.

The liquidity level was found to have a negative effect on the return on equity of the commercial banks in Kenya. The effect was however found to be insignificant at all levels of 1 percent significance level $(\mathrm{P}-\mathrm{value}=$ 0.008). Empirical results indicate that a one-unit increase in the bank liquidity levels above the minimum requirement reduced the banks return on equity by 47.4882 units holding other factors constant. The negative effect of liquidity levels on the financial performance of banks could indicate that holding high levels of liquidity has a cost in terms of foregone opportunity of lending. Liquid bank implies foregone opportunity for lending thus inhibiting bank's ability to convert its liabilities (demand deposits) to assets. Further, a high liquidity requirement may imply reduce financial resources at the disposal of the bank for lending thus adversely affecting its financial performance negatively. The findings agree with Muriithi (2017) found that short and long-term profitability of the banks had a negative relationship with bank liquidity levels.

Credit risk level was found to have a negative effect on the return on equity of the commercial banks in Kenya. The effect was however found to be significant at one percent significance level $(\mathrm{P}-\mathrm{value}=0.016)$. Empirical models results indicate that a one-unit increase in the credit levels reduced the banks return on equity by 3.4347 units holding other factors constant. Bank size was found to have a positive effect on the return on equity of the commercial banks in Kenya. The effect was however found to be significant at one percent significance level (P value $=0.000$ ). Empirical models results indicate that a one-unit increase in the credit levels reduced the banks return on equity by 6.0560 units holding other factors constant. The findings agree with Kargi (2011) who found out that the levels of advances, loans, deposits, and non-performing loans were also found to have an inverse affiliation with the banking institution's profitability in Nigeria. Further, the study findings on the negative effect of credit risk on banks' financial performance collaborate the findings by Mureithi (2012) who found out that there was a negative affiliation between banks profitability and credit risk in Kenya.

Bank size was found to have a positive effect banks' return on equity. The findings agree with the findings by Dogan (2013), who carried out a study on 200 companies which were active in Istanbul Stock Exchange for $2008-2011$. The result of analysis indicated a positive relation between size indicators and profitability of firms. A study by Gatete (2015), on the effect of bank size on the profitability of commercial banks in Kenya found out that firm size is statistically significant and moderately positively correlated to profitability of commercial banks in Kenya.

Table 1.3: Random Effects Regression Model

\begin{tabular}{lccccccc}
\hline Roe & Coef. & St. Err. & t-value & p-value & \multicolumn{2}{c}{$[95 \%$ Conf Interval] } & Sig \\
\hline Capital adequacy & 11.8177 & 6.4034 & -1.85 & 0.071 & -24.3683 & -0.732888 & $*$ \\
Liquidity & -47.4882 & 7.6693 & -6.19 & 0.008 & -62.5198 & -32.4565 & $* * *$ \\
Credit risk & -3.4347 & 2.1844 & -1.57 & 0.016 & -7.71601 & -0.846576 & $* *$ \\
Bank size & 6.0560 & 1.0940 & 5.54 & 0.000 & 3.911696 & 8.200281 & $* * *$ \\
Constant & 83.9533 & 19.7020 & -4.26 & 0.000 & -122.569 & -45.338 & $* * *$ \\
\hline
\end{tabular}

$* * * p<0.01, * * p<0.05, * p<0.1$

\subsection{Summary conclusion and recommendations}

\subsection{Conclusion}

The study concludes that an increase in capital adequacy levels above the minimum requirement has a positive effect on the increases the banks return on equity. The capital adequacy ratio, also generally known as capital to risk-weighted assets ratio, measures a bank's financial strength by using its capital and assets. It is used to protect depositors and promote the stability and efficiency of financial systems around the world. Therefore, banks with higher capital adequacy ratio above the minimum requirement by the regulator are perceived to be more stable and efficient. This is because a bank with a high capital adequacy ratio is considered safe and likely to meet its financial obligations. This builds confidence of the investors and the customers as well thus having a positive effect on the overall banks' performance.

The liquidity risk was found to have a negative effect on the return on equity of the commercial banks in Kenya. The negative effect of liquidity levels on the financial performance of banks could imply that holding high levels of liquidity has a cost in terms of foregone opportunity of lending. A high liquid level in the bank implies foregone opportunity for lending thus inhibiting bank's ability to convert its liabilities (demand deposits) to assets. This calls for the bank to diversify their products and services as well as the alternative investments opportunities to ensure the banks hold optimal liquidity at any point in time. 
The negative effect of credit risk on bank's financial performance implies that the quality of the bank's assets is a crucial determinant of bank's profitability. As such, proper credit vetting and consequently pricing risk at market rate need to be adhered to ensure good quality of the bank's assets. The loan recovery strategy put into place by the banks is crucial in determining the bank's assets quality. Moreover, diversification of bank lending across sector is core in diversifying banks risks by cushioning banks from specific - sector shocks that may adversely affect performance of such specific sector and consequently the repayments of loans led to such sector.

Lastly, the positive effect of bank size on the financial performance of bank implies several dynamics. First, a large bank is more likely to have competitive advantage in the market in terms of economies of scale hence can competitively price its products in the market. Secondly is the ability of the large banks to secure liquidity for lending at cheaper cost from various avenues such as the interbank market, hence having competitive advantage. In addition is the ability of large banks to raise collateral for lending when mobilizing funds for lending to their clients. Lastly could be the competitive advantage in terms of large customer base leading to benefits of economies of scale.

\subsection{Policy Implications}

Based on the study findings, several policy implications are pronounced. First, on the capital adequacy there is need for the commercial banks managers and board members to consider always keeping their capital adequacy far above the minimum requirement. This will help banks win public confidence and investor confidence by being perceived to be stable and efficient in its operations thus positively affecting its financial performance. In addition, given the positive effect capital adequacy has on the financial performance of the banks and the overall banking industry performance and financial sector at large, this has a policy direction to the industry regulator and the National Treasury, which is the overseer of the financial sector. The Central Bank of Kenya and the National Treasury should consider acceleration of the full implementation of the Basel III, which focuses on maintaining proper leverage ratios, and meet certain minimum capital requirements.

Regarding the credit risk, the finding of the study was that credit risk adversely affects the banks' financial performance. This calls into the need for more regulation guidelines around the credit risk aspects. For instance in the current wave of emerging digital lending, regulation guidelines on the quality of digital loans are long overdue given the large volumes digital loans advances that is necessitated by their ease of access for the mere fact that the requirements are few and amounts involved are small. In addition, are the government's policies geared towards de - risking the core sectors which commercial banks have a bias on lending to lower the probability of defaults risk.

\subsection{Suggested Areas for Further Research}

This study focused on the effect of the firm characteristics on financial performance of commercial banks in Kenya. In doing so, the study focused on four characteristics namely: capital adequacy, liquidity, credit risk and bank size. Based on the scope of the study a number of areas for further studies are elicited.

First, the future studies in this area can consider undertaking tier level analysis. This could entail running regressions for tier one category, tier 2 and tier 3 category analysis, to determine in which tier the effect of the different firm characteristics is more pronounced than the other. This would inform the management of the banks on the appropriate policies that suit their bank based on which tier their bank belongs to.

Secondly, future studies can consider undertaking inter - industry analysis on how firm characteristics affect the financial performance of the different industries within the financial sector. To this effect, such studies can conduct analysis for banking industry, insurance industry, saccos and pension firms and carry out financial sector inter industry analysis. This would be informative in comparing which industry within the financial sector is more affected by the firm characteristics compared to others with regard to its profitability.

Thirdly, future studies in this area could consider broadening the scope of the firm characteristics and consider more characteristics management efficiency, capital structure, ownership structure, firm age and technology adoption.

\section{References}

Abiola, I., \& Olausi, A. S. (2014). The Impact of Credit Risk Management on the Commercial Banks Performance in Nigeria. International Journal of Management and Sustainability, 3 (5): 295, 306.

Baltagi, B.H. (2005). Econometric analysis of panel data (third ed.) John Wiley \& Sons

Berger, A.N., \& Bouwman, C. H. (2013). How does capital affect bank performance during financial crises? Journal of Financial Economics, 109(1), 146-176.

Central Bank of Kenya (2013). Prudential Guidelines for Institutions Licensed Under the Banking Act. 70-92

Central Bank of Kenya (2010). Bank Supervision Annual Report 2010, 38-45.

Central Bank of Kenya (2011). Bank Supervision Annual Report 2011, 53-62.

Central Bank of Kenya (2012). Bank Supervision Annual Report 2012, 65-74. 
Central Bank of Kenya (2013). Bank Supervision Annual Report 2013, 68-78.

Central Bank of Kenya (2013). The Role of Development Financial Institutions in Kenya. Paper presented at the 2013 Annual Association of African Development Finance Institutions Forum. Serena Beach Hotel, Mombasa Kenya.

Central Bank of Kenya (2014). Bank Supervision Annual Report 2014, 57-67.

Central Bank of Kenya (2015). Bank Supervision Annual Report 2015, 50-60.

Central Bank Kenya, (2015). Bank supervision Annual report. [Online] Available: http://www.centralbank.go.ke Central Bank of Kenya (2017). Bank Supervision Annual Report 2017, 1-106.

Chowdhury, A., \& Żuk, P. (2018). From crisis to crisis: Capitalism, chaos, and constant unpredictability. The Economic and Labor Relations Review, 29(4), 375-393.

Family Bank. (2017). Integrated Report \& Financial Statements. Retrieved from https://familybank.co.ke/wpcontent/uploads/2018/08/Family-Bank-2017-Integrated-Report.pdf

KPMG (2013). From Burden to Competitive Advantage. Regulatory Change and Transformation in Financial Services. KPMG Transformation Survey, 3-5.

Mureithi, C. W. (2012) Effect of Financial Regulation on Financial Performance of Deposit-Taking Microfinance Institutions in Kenya. Unpublished MBA Research Project, University of Nairobi, School of Business.

Naceur, S. B., \& Omran, M. (2011). The effects of bank regulations, competition, and financial reforms on banks' performance. Emerging Markets Review, 12(1), 1-20.

National Bank of Kenya (2016). National bank of Kenya reports sh. 1.2 billion pretax loss in 2015. \{Online\} available: https://www.standardmedia.co.ke

Ogboi, C., \& Unuafe, O. K. (2013). Impact of Credit Risk Management and Capital Adequacy on the Financial Performance of Commercial Banks in Nigeria. Journal of Emerging Issues in Economics, Finance, and Banking, 2(3), 703-717.

Otiato, G. (2017, April 1). How family Bank lost 23 Billion in Five Days. Standard Media. Retrieved from https://www.standardmedia.co.ke/article/2001234728/how-family-bank-lost-sh23-billion-in-five-days

Poudel, R. P. S. (2012). The impact of credit risk management on the financial performance of commercial banks in Nepal. International Journal of Arts and Commerce, 1(5), 9-15 